\title{
Analysis on the Influence Factors of Real Estate Price in Linyi City
}

\author{
Zhongxiu Liu \\ School of Civil Engineering and Architecture, Linyi University, Linyi City, Shandong Province, China \\ liuzhongxiu@lyu.edu.cn
}

Keywords: Real Estate Price; Demand; Supply; Influencing Factors; Linyi city

\begin{abstract}
As an important industry in the national economy, real estate plays an extremely important role in China's economic development. The health status of a city's real estate development plays a vital role in this city's construction. However, judging whether the development of the real estate industry is the main criterion of health is the real estate price fluctuations are normal. This paper summarizes the relevant literatures on the real estate price theory both at home and abroad. Analysis of the housing prices in Linyi City, since 2006, a steady increase in sales has increased year by year. And from the supply demand factors, macroeconomic and other aspects of the impact of real estate prices do qualitative analysis of the factors. Based on the qualitative analysis and the data collected from Linyi Statistical Yearbook, this paper chooses the real estate investment, housing construction and completion area, real estate cost and demand factor in the supply factors, the income level of urban and rural residents, price index and inflation rate, and other factors in the GDP, interest rates, taxes, psychological and other factors, the impact of real estate prices in Linyi City, the factors were analyzed.
\end{abstract}

\section{Introduction}

In 1998, China's commercialization of housing reform, real estate prices show a rising trend. Rapid rise in house prices, not only on the healthy development of the national economy have a certain negative impact, but also reduces the quality of life of residents. Excessive housing prices has become a cause of widespread concern about economic and social problems.

China's real estate industry has become an indispensable part of national economic development, issued by the end of August 2003, "the State Council on the promotion of sustainable and healthy development of the real estate market notice" clearly states that "the real estate industry associated with high driving force has become a national economic pillar industry ", in this context, the study of real estate prices is very important.

Linyi City as a "logistics capital, trade city", the rapid economic development, the real estate market has a strong representation. So take Linyi City real estate as an example, this paper researched real estate price changes and its impact factors.

\section{The Real Estate Prices Affect the Literature Review}

In the existing literature research, the analysis of the factors affecting the real estate prices mainly from the following angles.

All along the real estate prices related to attract a large number of scholars concerned. Abrahma and Hendershott (1996) show that residential prices are related to housing construction costs, employment rates and household incomes by examining a housing price change model that takes into account the lagging process. It also points out that the rise in housing prices and the rise in interest rates are negative To change the relationship between [1]. Englund and Ioannides (1997) selected 15 countries in the OECD real estate prices for the study, found that GDP growth has a positive effect on house prices, and interest rates on house prices have negative effects. Quighey (1999) studied the annual data of 41 urban agglomerations in 1986-1994 in the United States, and concluded that macroeconomic fundamentals have some explanatory power to real estate prices. Economic 
fundamentals and their changes are the main factors of real estate price changes, the use of it can explain and predict the trend of housing price changes.

Peng and Wheaton conducted an empirical study of the situation in Hong Kong from 1965 to 1990. The results showed that the supply of land had a great impact on house prices, and the shortage of land supply coupled with the expectation of consumers led to the common rise of land price and house price. By constructing a housing price model that includes a lagged process, Abraham and Hendershott reveal that house prices are directly related to construction costs, employment rates, and incomes, and that price increases are negatively correlated with interest rates. Harris studied the effect of real interest rate and nominal interest rate on real estate prices, and found that the change of real interest rate could explain the market price level. Nominal interest rate only played a role in the formation of real estate appreciation expectation.

Domestic scholars for China's rising real estate prices, from different angles on its determinants of the study. Shen Yuehe Liu Hongyu (2004) through the analysis of 14 cities in China from 1995 to 2002 that the economic fundamentals of the interpretation of the housing price level model there is a significant impact on the characteristics of the city in recent years, the growth of residential prices have been unable to use Economic fundamentals and housing prices of historical information to explain. Sheng Songcheng (2007) Through the empirical analysis of the relationship between economic development and housing price rise in Japan, the United States, China and Shanghai, the author thinks that there is a clear causal relationship between economic development and housing price, economic development plays a decisive role in the long-term trend of housing prices. Focus on needs. Wu Jinglian (2007) argues that there is a gap between money supply growth and GDP growth plus inflation, which indicates that a large number of unrealized currencies accumulate. They do not appear in commodity markets, nor in inflation, While the performance for the real estate price inflation. [2]

Since the 1990s, the negative relationship between interest rates, bank credit and real estate prices has been questioned by some literature (Gerlach \& Peng, 2005). In China's real estate price decision, the domestic scholars also conducted a different perspective. Zhou Jingkui studied the relationship between housing prices and monetary policy and bank loans in four municipalities in China, believing that loose monetary policy led to a rise in house prices in China. However, some scholars have found that in China, the relationship between bank interest rates and real estate is not obvious (Liang Yunfang, Gao Tiemei, 2007). The relationship between real estate prices and land prices has also been widely concerned. Ping Xinqiao that the rise in land prices to promote the rise in house prices. Yan Jinhai analyzed the relationship between house price and land price in China. The results show that there is mutual influence between the two in the long run, while in the short term, the house price determines the land price, while the land price has little effect on the house price. When the supply exceeds demand, house prices and land prices become a linear negative correlation; in the supply less than demand, the price and land prices into a linear positive correlation. Based on the data of 1999-2004 and the undervaluation of the RMB exchange rate estimated by the relevant research, this paper argues that the undervaluation of the exchange rate will cause the economic structure to tilt, and then the underestimation of the economic structure caused by the adjustment of the exchange rate will lead to the rise of real estate prices . In addition, the government land regulation is also considered to be an important reason for the rapid rise in house prices. [3]

\section{Linyi City Real Estate Prices}

Linyi is located in the southeast of Shandong Province, near the Yellow Sea, south of Jiangsu. Yinshui, Mengyin, Pingyi, Fei County, Yinan, Linshu 9 counties, with a total area of 17,200 square kilometers, population 1041.5 Million, is the largest in Shandong Province, the largest population of the municipal administrative regions. Linyi is a clear advantage of the location of the transport hub city. Beijing, Shanghai, Guangzhou, Qingdao and other domestic more than 20 routes converged here. The two railways in Beijing, Shanghai, Guangzhou, Qingdao and other domestic more than 20 routes 
here. Linyi from Rizhao Port, Lianyungang, Lanshan Port are about $100 \mathrm{~km}$ away from Qingdao Port $200 \mathrm{~km}$ north-south intersection, land and sea and economic development of a vast space. Linyi city is the national civilized city to create advanced cities, the national environmental protection model city, the national double-support model city, China Excellent Tourism City, the National Garden City, the Chinese book culture of the hometown of Chinese culture Zhuge Liang, Chinese calligraphy city, China geothermal City, China 's investment environment and the country' s top 100 Park City, one of the eight red tourism key cities. [4]

Linyi real estate market at this stage the development of relatively stable and strong demand, through the collection of the Linyi City, 2006-2012 data analysis to determine their respective variables on the impact of housing prices.

From 2006 to enter the rapid development of real estate in Linyi stage, the rapid increase in real estate sales area. In 2012 the city's commercial housing sales area of 7.278 million square meters, an increase of $13.65 \%$.

Through the study of the chart we found that average housing prices in Linyi City from 2006 to 2011 is a sustained growth trend, indicating that Linyi real estate prices in a period of steady rise in sales in the past few years Linyi housing Although sales are showing an annual growth trend.

\section{Linyi City Real Estate Prices Affect the Factors}

\subsection{The influence of supply factors on real estate prices in Linyi}

4.1.1Real Estate Investment in Linyi City. Real estate development investment is the amount of real estate development companies, real estate construction companies and other real estate development and legal entities affiliated to other legal entities engaged in real estate development or business activities of the unified development of units, including factories, warehouses, demolition also built houses, Office buildings and other buildings and ancillary services, land development projects (such as roads, water supply, drainage, power supply, heating, leveling the site and other infrastructure projects) investment. It is an important part of investment in fixed assets, is to reflect the macroeconomic boom is an important indicator. In 2005 the new national control policies introduced, Linyi City housing prices stabilized, and growth, real estate investment scale growth. Since 2006 showed a rapid growth trend, especially in 2008 for the most.

4.1.2 Floor Space of Residential Buildings and Floor Space of Residential Buildings. Housing construction area, as the name suggests refers to the real estate industry in the statistical period of the construction of all the housing housing area, including the current period of new housing area, on the completion of the completion of the construction of the current housing construction area, The area of houses built in the current period, the area of houses completed in the current period and the area of houses that have been suspended or deferred after construction.

Housing completed area in the reporting period refers to the completion of residential housing in accordance with the design requirements to achieve the conditions for people to live and use, approved by the relevant departments after the acceptance of qualified, the official transfer to the use of units and the sale of housing housing area .

The housing construction area includes the completion area ofhouses and houses, both of which have strong positive correlation. Therefore, these two indexes can be used as the supply factors influencing the price of real estate. The housing completion area will mainly affect the supply of the real estate market, while the housing construction area will not only supply the current real estate market, but also affect the supply of the next phase of the real estate market, and then affect the real estate prices. This paper analyzes the area of housing completed in Linyi City in 2006-2012 (only in January-November 2012), and explains the impact of housing construction area and completed area on its price.[5]

It can be seen that the area of completed housing in Linyi City has maintained a growth trend, indicating that with the increasing demand, the supply of real estate is also rising, housing 
construction area in 2006 has slowed, which led to the 2009 And in 2010 the completion of the housing area reduction, after 2010 housing completion area of residential growth.

4.1.3 real estate costs. Real estate costs, including construction costs and land costs, when the real estate development costs increase, the profits will be reduced, developers will reduce the real estate development, so that the supply of real estate to reduce the price of real estate will increase; the contrary, the increase in real estate supply, Real estate prices lower.

\section{2 the impact of demand factors on real estate prices in Linyi City}

4.2.1 Income Level of Urban and Rural Residents. The increase in real income of urban and rural residents will increase their ability to pay, thus increasing the demand for real estate, leading to real estate prices. Income increases the impact on housing prices, depending on the existing income level and the size of the marginal propensity to consume. For low-income families, although the marginal propensity to consume larger, but its increased income is mainly used to meet the basic necessities of life such as food and clothing, the impact on housing prices smaller; for middle-income families, the marginal propensity to consume larger, The increase in income will be used to improve the quality of life, including housing quality, resulting in high prices; high-income families have less marginal propensity to consume, but if the increased income for real estate investment or speculation, will cause real estate Prices rise.

Linyi City, urban and rural incomes increased significantly, the living standard continues to improve.

4.2.2 Changes in family size. Real estate, especially the real estate demand is the main body of people, the number, quality, composition and other conditions have a greater impact on real estate prices. When the population increases, the demand for real estate will increase, the real estate prices will rise, on the contrary, it will decline. The causes of urban population change are due to the natural increase of population and the change of population migration. Improve the quality of the population will also cause prices to improve. With the progress of civilized society, public service facilities will become increasingly perfect and universal, while the quality of living will put forward higher requirements, resulting in real estate prices. Changes in the size of the family population, will cause changes in the number of living units, thereby causing changes in real estate demand, resulting in changes in real estate prices. In the November 1, 2010 zero hour of the sixth census in Linyi City, the city's resident population of 1003.94 million, a family of 3303,800 households, household population of 971.5 million, the average household population is 2.94 people, compared with the 2000 fifth national census of 3.18 people reduced by 0.24 people. In general, with the small size of the family population, an increase in the number of families, the total amount of housing will increase, the real estate prices will rise ${ }^{[6]}$.

4.2.3Price Index and Inflation Rate. The price index and the inflation rate mainly influence the real estate economy fluctuation through two ways. First, the inflation rate affects the real estate nominal and real price changes, price index or inflation rate and real estate prices there is a clear positive correlation between. On the one hand, when the overall trend of rising prices, the real estate nominal prices rise. On the other hand, building materials prices, construction labor costs will drive up real estate production costs, resulting in rising house prices. Second, the inflation rate makes the impact of real estate commodity hedging and value-added functions change, thereby affecting the real estate economic fluctuations.

\subsection{The influence of other factors on real estate prices in Linyi}

4.3.1Gross Domestic Product. GDP is an effective measure of the overall economic situation of a country and an area and is an important economic indicator that can represent the level of economic development of a country or a region. GDP growth proves that the overall purchasing power of a country and an increase in demand for housing at the same time also increased, it will push up the price level of the real estate market. Linyi City's GDP has been steady growth, is the Linyi city to see the real estate market prices an important reason for growth. In order to better analyze the impact of GDP on real estate prices, we can focus on the 2006-2012 gross domestic product, in order to provide the basis for the investment decision-making. 
Since 2006, the GDP of Linyi City is increasing year by year, the GDP in 2012 reached 301.281 billion yuan, an increase of $8.7 \%$.

4.3.2 The Impact of Bank Interest Rate Change on Real Estate Price in Linyi City. From a theoretical point of view, according to Keynesian point of view, bank interest rates and real estate prices are inversely proportional relationship, when the interest rate increases, the income of other investment methods will increase, so that investors on the real estate investment behavior decreased, the amount of investment reduced Resulting in real estate prices lack of support, the corresponding housing prices will fall; secondly for developers in terms of loan interest costs, while prices remain unchanged, this part of the increase in the cost can not be passed on to real estate prices, the price is not Change on the basis of the corresponding increase in the cost of capital investment income will be reduced, the real estate market will be significant cooling, leading to falling prices. On the contrary, when the interest rate to a certain extent, all aspects of the increased demand for capital, the economy began to revive, more and more funds into real estate, thereby promoting housing prices [7].

4.3.3 The Impact of Tax Policy on Real Estate Price in Linyi City. Different taxes, tax rates and levies, the impact on real estate prices are different. Taxes can be divided into real estate development aspects of the tax, real estate transactions and tax aspects of real estate to maintain the link tax. In addition, the tax policy on the impact of real estate prices, we must pay attention to the transfer of tax issues. If a certain tax on real estate can be passed in some way or all of the way out, then its impact on real estate prices is small, or even ineffective. On the contrary, lowering or even eliminating the taxation of real estate will result in the rise of real estate prices ${ }^{[8]}$. In fact, the real estate industry is not a real estate market.

4.3.4 The Impact of Psychological Factors on Real Estate Price in Linyi City. Psychological factors will also greatly affect the real estate price changes. The psychological factors that affect real estate prices are the following: (1) mentality when buying and selling; (2) personal habits; (3) social atmosphere.

When the purchase of consumer demand to select a suitable real estate, they will try every means to buy the real estate. The demander usually takes various effective and legal measures to facilitate the transaction, usually under the market will be higher than the price to buy it. Therefore, this type of transaction will naturally make the transaction price higher than the normal market price ${ }^{[9]}$.

\section{Conclusion}

In general, the factors that affect the price of real estate in Linyi City are diverse, these factors in addition to their direct impact on real estate prices, various factors also affect each other, such as interest rates will directly affect the real estate prices, but also Affect the real estate development investment, consumer expectations and so on. Moreover, the real estate prices will in turn affect these factors, such as real estate prices on land supply, the scale of real estate investment will also be affected. Real estate prices and the interaction of these factors make the real estate price changes become interlocking, intricate. On the basis of qualitative analysis, the author analyzes qualitatively and quantitatively the influencing factors of real estate price in Linyi City, and provides the theoretical basis for the regulation of the real estate market in China as an important subject for urgent research. A country and local economy is in a stage of rapid development, there must be a real estate industry to drive, which is building a moderately prosperous society to improve the quality of life the only way. In accordance with internationally accepted algorithm, per capita floor area of 30 square meters before the per capita GDP in the 800 - 1500 US dollars between the residential and real estate development is the high-speed period. Linyi urban per capita housing area in 2006 is only about 20 square meters, per capita GDP of nearly 1200 US dollars, is in the rapid development of residential and real estate stage, and now developed into a comprehensive well-off society and achieve the level of moderately developed countries, Now the pace of economic development, there will be a longer period of time, therefore, Linyi City, the real estate industry has great potential for sustainable development. 


\section{References}

[1]Abraham. J. M. and P. H. Hendershott, Bubbles in Metropolitan HoL: sing, Journal of Housing Researsh, 1996, pp.

[2]Lin Wengao, Real Estate Price Impact Factor Analysis: Guangdong Foshan data test, Southern Finance, 2012, (3):

[3]Dong Zhiyong, Guan Hao, Ming Yan, Analysis of the Factors Affecting Real Estate Price: An Empirical Study Based on Panel Data of Chinese Provinces and Cities, Journal of China University of Geosciences, 2010,10 (2): 98-103

[4]Linyi Overview, http://www.linyiexpo.gov.cn/News/316.html, Linyi Exhibition Network, 2011-3-8

[5]Linyi City Statistical Yearbook (2007-2012), http: //www.stats-ly.gov.cn/linyi/tjsj/ndsj/index.html, Linyi Bureau of Statistics public information network, 2013-9-8

[6]Baidu library, Linyi City in 2010 the Sixth National Census of the Main Data Bulletin, http://wenku.baidu.com/view/7254696127d3240c8447ef23.html, 2011-5-7

[J]Central University of Finance and Economics, 2006 (1): 54-59. WANG Jia-ting, ZHANG Huai-zhao.Empirical Analysis on the Impact of Interest Rate Fluctuation on China's Real Estate Market [J]

[8]Chen Shengguang. Real estate tax policy interpretation of the new [J]. China Real Estate Information, 2006 (5): 45-46.

[9]Li Fei. Psychological Expectations in the Role of Price Regulation [J]. The real estate market, 2008,9: 24-25 